Vegetalika. 2020. 9(2): 399-413

\title{
Identifikasi Karakter Morfologi dan Agronomi Penentu Kehampaan Malai Padi (Oryza sativa L.)
}

\author{
Identification of Morphology and Agronomy Characters of Rice \\ (Oryza sativa L.) Panicle Void
}

\author{
Lidwina Arum Meta Widyaningtias, Prapto Yudono, Supriyanta* \\ Departemen Budidaya Pertanian, Fakultas Pertanian, Universitas Gadjah Mada \\ Jalan Flora No. 1, Bulaksumur, Sleman, Yogyakarta 55281, Indonesia. \\ *)Penulis untuk korepodensi E-mail : supriyanta@ugm.ac.id
}

\begin{abstract}
Morphological and agronomical characters such as a lot of the number of grains per panicle, such as wide, thin, horizontal, and fast decaying leaves, and early maturity are the determinants of grain emptiness in rice panicles in New Type of Rice (NTR). Emptiness in panicles is caused by genetic and environmental factors. The purpose of this study was to identify the morphological components of rice to determine the cause of panicle emptiness. Twenty-one rice cultivar and variety was planted at the Universitas Gadjah Mada Agro Technology Innovation Center (PIAT) in Kalitirto, Berbah, Sleman Regency, Special Region of Yogyakarta from March to August 2018 using a Randomized Block Group Design (RCBD) with three replications. Furthermore, it was analyzed by analysis of covariance (ANCOVA) followed by correlation analysis and path analysis. Based on experiments that have been carried out, the emptiness could reduce grain filled by $29.33 \%$. This due to morphology and agronomy characters that cause the panicle emptiness include flag leaf length, productive tillers, panicle density and grain content, this is based on correlation analysis that has been done. These characters are genetically diverse so that they can be used as selection criteria to reduce emptiness. Accession number 91 or black $Q$ and 23 or UGM * 2 has a low voidness of $9.68 \%$ and $9.92 \%$ respectively, homogeneous homozygous can be used as crossing parents so that in the end the results can be increased by decreasing voidness.
\end{abstract}

Keywords: rice, emptiness in rice panicle, morphology, agronomy

\section{INTISARI}

Karakter morfologi dan agronomi seperti jumlah gabah per malai banyak, daun lebar, tipis, mendatar, dan cepat luruh, serta berumur genjah merupakan karakter penentu kehampaan gabah pada malai padi pada Padi Tipe Baru (PTB). Kehampaan gabah pada malai disebabkan oleh faktor genetik dan lingkungan. Tujuan penelitian ini untuk mengidentifikasi komponen-komponen morfologi padi untuk mengetahui penyebab kehampaan malai. Dua puluh satu padi kultivar dan varietas ditanam di Pusat Inovasi Agro Teknologi (PIAT) Universitas Gadjah Mada (UGM) di Kalitirto, Berbah, Kabupaten Sleman, Daerah Istimewa Yogyakarta pada 
bulan Maret hingga Agustus 2018 menggunakan rancangan Rancangan Acak Kelompok Lengkap (RAKL) dengan tiga ulangan. Selanjutnya dianalisis dengan analysis of covariance (Ancova) kemudian dilakukan analisis korelasi dan analisis lintas (path analysis). Berdasarkan percobaan yang telah dilakukan, kehampaan mampu mengurangi gabah isi sebesar $29.33 \%$. Karakter morfologi dan agronomi yang menyebabkan kehampaan malai ini antara lain panjang daun bendera, anakan produktif, kepadatan malai dan gabah isi, hal ini berdasarkan analisis korelasi yang telah dilakukan. Karakter tersebut beragam secara genetik sehingga dapat digunakan sebagai kriteria seleksi menurunkan kehampaan. Aksesi nomor 91 atau $Q$ hitam dan 23 atau UGM*2 memiliki kehampaan rendah masing-masing sebesar $9.68 \%$ dan $9.92 \%$, bersifat homogen homozigot dapat digunakan sebagai tetua persilangan sehingga pada akhirnya hasil bisa ditingkatkan dengan menurunkan kehampaan.

Kata kunci: agronomi, kehampaan malai, morfologi, padi.

\section{PENDAHULUAN}

Padi merupakan tanaman pangan utama yang dibudidayakan di Indonesia. Produksi padi lebih dari $90 \%$ dihasilkan di lahan persawahan. Hal ini dikarenakan lahan persawahan umumnya memiliki kondisi optimal yang mendukung tanaman padi untuk tumbuh dengan baik. Namun, fakta di lapangan kondisi optimal tersebut ternyata tidak menjamin tingginya produktivitas padi sawah. Salah satu penyebab permasalahan tersebut adalah kehampaan gabah sebesar lebih dari 15\% (Kodir et al., 2018). Oleh karenanya diperlukan tanaman padi yang tetap mampu berproduksi tinggi dengan tingkat kehampaan gabah yang rendah.

Peningkatan produksi tanaman padi dapat dilakukan dengan memodifikasi tipe tanaman. Adanya modifikasi tipe tanaman ini maka akan meningkatkan produksi bahan kering tanaman dan indeks panen sehingga dapat meningkatkan potensi hasil. Salah satu metode yang digunakan yaitu dengan melakukan karakterisasi morfologi dan agronomi tanaman tersebut. Adanya kegiatan karakterisasi ini dapat diketahui kultivarkultivar yang memiliki karakter morfologi dan agronomi kehampaan rendah maupun tinggi.

Kehampaan gabah merupakan kosongnya sekam akibat isi atau bulir gabah tidak terbentuk karena faktor internal maupun eksternal. Kehampaan ini merupakan salah satu faktor utama penyebab rendahnya produktivitas padi. Penyebab kehampaan dapat dikarenakan tidak sempurnanya penyerbukan akibat kerusakan gamet jantan dan betina, serta tidak seimbangnya sink (lubuk) yang besar dan source (sumber) yang sedikit. Karakter morfologi dan agronomi pada malai tanaman padi yang menjadi penyebab kehampaan misalnya jumlah gabah per malai banyak, tetapi sumber kurang mendukung, seperti daun lebar, tipis, mendatar, dan cepat luruh, serta berumur genjah, 
sehingga asimilat yang dihasilkan rendah dan kurang mencukupi untuk pengisian gabah yang mengakibatkan kehampaan semu (Abdullah et al., 2008). Selain itu menurut Kobata et al. (2002) tingginya kehampaan disebabkan oleh tingkat kemasakan bulir padi yang rendah. Salah satu penyebabnya adalah rendahnya kapasitas akumulasi asimilat pada malai (Yamagishi et al., 1996). Gabah yang terletak pada ujung dan pangkal malai memiliki perbedaan panjang masa pengisian bulir dan waktu masak. Menurut Peng et al. (1994) terdapat kecenderungan gabah isi yang tinggi terletak pada cabang primer dan sekunder yang terletak diujung malai. Sebaliknya, cabang primer dan sekunder yang terletak dekat pada leher malai cenderung memiliki gabah hampa yang tinggi.

Fakultas Pertanian Universitas Gadjah Mada memiliki koleksi padi yang memiliki potensi sebagai galur harapan. Adanya identifikasi karakter morfologi dan agronomi ini akan didapatkan informasi mengenai karakter-karakter penentu kehampaan malai. Selain itu diharapkan juga bermanfaat untuk program pemuliaan tanaman khususnya dalam pembuatan tanaman padi dengan kehampaan malai yang rendah.

\section{BAHAN DAN METODE}

Penelitian ini dilaksanakan di Pusat Inovasi Agro Teknologi (PIAT) Universitas Gadjah Mada di Kalitirto, Berbah, Sleman, Yogyakarta pada bulan Maret hingga Agustus 2018. Bahan yang digunakan dalam penelitian ini adalah 21 galur tanaman padi koleksi Fakultas Pertanian Universitas Gadjah Mada antara lain Sembada hitam, MSP-18 hitam, Inpago 5, Situ Patenggang, Arif, Inpago 6, UGM 2*, BH, NN-3, NN-5, NN-9, Situbagendit, BF hitam, Q hitam, AM hitam, J hitam, BK hitam, AN hitam, AH hitam, IR 64, Situpatenggang-1, pupuk Urea, SP-36, KCl. Peralatan yang digunakan adalah alat dan sarana produksi pertanian untuk pertanaman padi, meteran, kantong plastik, timbangan elektrik, alat tulis, kamera. Rancangan yang digunakan dalam penelitian ini adalah Randomized Block Design (RCBD) terdiri dari tiga blok berfungsi sebagai ulangan dengan menggunakan 21 galur tanaman padi sebagai perlakuan. Setiap nomor yang sama ditanam secara acak dalam tiap blok yang terdiri dari 3 baris sepanjang $400 \mathrm{~cm}$ x $60 \mathrm{~cm}$ dengan jarak tanam $20 \mathrm{~cm} \times 20 \mathrm{~cm}$ dan jarak antar blok adalah $100 \mathrm{~cm}$.

Tahap pelaksanaan penelitian ini adalah persiapan lahan, persemaian, penanaman, penyulaman, pengairan, pemupukan, pengendalian organisme pengganggu tanaman dan gulma, panen, dan pengamatan. Persiapan lahan terdiri dari pengolahan lahan dan pembuatan layout penelitian, persemaian benih padi pada lahan yang berukuran $1 \mathrm{~m}$ x $3 \mathrm{~m}$ hingga berumur 21 hari setelah semai. Penanaman dilakukan 
dengan sistem pindah tanamn pada saat benih berumur 21 hari setelah semai dengan setiap lubang terdiri atas 2-3 bibit dengan jarak tanam $20 \mathrm{~cm} \times 20 \mathrm{~cm}$ serta tiap nomor tanaman padi ditanam 20 titik pada tiga baris sebanyak tiga kali. Penyulaman dilakukan terhadap tanaman yang mati atau tanaman yang tumbuhnya kurang normal. Pengairan dilakukan untuk memenuhi kebutuhan air. Pemupukan dilakukan sebanyak empat kali yaitu pemupukan pertama adalah pemupupukkan dasar dengan pupuk kandang yang sudah masak sebanyak 1 ton/ha pada saat pengolahan lahan, pemupukan kedua adalah pemupukan pemupukan susulan yang pertama yang diaplikasikan pada umur 7 hst dengan dosis Urea 100 kg.ha-1, SP-36 75 kg.ha-1 dan KCl 75 kg.ha-1, pemupukan susulan kedua menggunakan Urea $100 \mathrm{~kg}^{\mathrm{ha}} \mathrm{h}^{-1}$ yang diaplikasikan pada $35 \mathrm{hst}$, pemupukan susulan ketiga menggunakan Urea $100 \mathrm{~kg}^{-h^{-1}}$ yang diaplikasikan pada 49 hst. Metode pemberian pupuk dengan cara menebarkan pupuk secara merata atau broadcasting. Pengendalian organisme pengganggu tanaman dan gulma disesuaikan dengan kondisi gejala dan serangan di lapangan. Sedangkan pengendalian gulma dilakukan dengan cara manual setelah umur 14 hst dilakukan sesuai dengan kondisi gulma dilapangan. Panen Panen dilakukan saat $90 \%$ bulir padi sudah menguning. Panen dilakukan secara manual dengan menggunakan sabit.

Pengamatan morfologi dan agronomi berdasarkan Karakterisasi dan Evaluasi Tanaman Padi yang diterbitkan oleh Departemen Pertanian (2003). Pengamatan dilakukan pada 3 tanaman sampel pada masingmasing petak-petak perlakuan dari 21 galur yang dipilih. Pengamatan terdiri dari aspek morfologi dan agronomi berupa tinggi tanaman, lebar daun bendera, panjang daun bendera, umur berbunga, umur panen, jumlah anakan produktif, panjang malai, gabah isi per malai, gabah hampa per malai, kepadatan malai, bobot 100 butir, kadar air, hasil, bentuk gabah, bentuk beras pecah kulit, dan warna beras pecah kulit. Data kuantitatif dianalisis dengan Analysis of Covariance (ANCOVA) pada taraf $5 \%$ dengan menggunakan program R. Kemudian dilakukan analisis korelasi secara fenotip dan genotip, dan analisis sidik ragam.

\section{HASIL DAN PEMBAHASAN}

Keragaman morfologi merupakan bentuk dan struktur tanaman yang membedakan antara satu tanaman dengan tanaman yang lain dan merupakan dasar klasifikasi tanaman serta digunakan sebagai alat untuk mengenal adaptasi tanaman terhadap lingkungan. Variabel yang menjadi karakter morfologi adalah panjang daun bendera, lebar daun bendera, panjang malai, kepadatan malai yang ditampilkan di tabel 
1 serta karakter sudut daun bendera, cabang malai sekunder, poros malai, tipe malai, bentuk gabah, bentuk beras, dan warna beras yang ditampilkan pada tabel 2 .

Tabel 1. Karakter Morfologi Panjang Daun Bendera, Lebar Daun Bendera, Panjang Malai, Kepadatan Malai 21 Nomor Tanaman

\begin{tabular}{|c|c|c|c|c|c|}
\hline $\begin{array}{l}\text { No } \\
\text { Aksesi }\end{array}$ & Nama Aksesi & $\begin{array}{l}\text { Panjang daun } \\
\text { bendera }(\mathrm{cm})\end{array}$ & $\begin{array}{l}\text { Lebar daun } \\
\text { bendera }(\mathrm{cm})\end{array}$ & $\begin{array}{l}\text { Panjang } \\
\text { malai } \\
(\mathrm{cm})\end{array}$ & $\begin{array}{l}\text { Kepadatan } \\
\text { malai } \\
\text { (butir/cm) }\end{array}$ \\
\hline 1 & Sembada hitam & $27.44 \pm 3.09$ & $1.72 \pm 0.06$ & $\begin{array}{ll}26.94 & \pm \\
0.92 & \end{array}$ & $6.67 \pm 0.87$ \\
\hline 3 & MSP-18 hitam & $33.56 \pm 5.83$ & $1.68 \pm 0.29$ & $22.7 \pm 0.89$ & $6.99 \pm 0.50$ \\
\hline 5 & Inpago 5 & $27.90 \pm 3.32$ & $1.74 \pm 0.25$ & $\begin{array}{l}21.97 \\
0.64\end{array}$ & $7.63 \pm 0.81$ \\
\hline 11 & Situ Patenggang & $23.30 \pm 2.96$ & $1.42 \pm 0.03$ & $\begin{array}{l}22.42 \\
0.38\end{array}$ & $7.02 \pm 0.48$ \\
\hline 17 & Arif & $28.31 \pm 5.17$ & $1.60 \pm 0.05$ & $\begin{array}{l}24.89 \\
0.85\end{array}$ & $8.45 \pm 1.03$ \\
\hline 22 & Inpago 6 & $25.12 \pm 0.94$ & $1.61 \pm 0.23$ & $\begin{array}{l}21.76 \\
2.04\end{array}$ & $9.55 \pm 1.03$ \\
\hline 23 & UGM 2* & $20.24 \pm 1.89$ & $1.33 \pm 0.07$ & $\begin{array}{l}21.43 \\
1.11\end{array}$ & $5.86 \pm 0.73$ \\
\hline 24 & $\mathrm{BH}$ & $32.81 \pm 8.32$ & $1.18 \pm 0.02$ & $\begin{array}{l}26.17 \\
0.73\end{array}$ & $7.30 \pm 0.20$ \\
\hline 53 & NN-3 & $25.57 \pm 7.41$ & $1.43 \pm 0.09$ & $\begin{array}{l}24.04 \\
0.69\end{array}$ & $8.59 \pm 0.84$ \\
\hline 55 & NN-5 & $26.09 \pm 3.38$ & $1.36 \pm 0.18$ & $\begin{array}{l}25.18 \\
1.44\end{array}$ & $6.57 \pm 1.03$ \\
\hline 59 & NN-9 & $18.84 \pm 1.05$ & $1.56 \pm 0.11$ & $\begin{array}{l}22.00 \\
0.40\end{array}$ & $7.25 \pm 0.46$ \\
\hline 66 & Situbagendit & $34.00 \pm 3.06$ & $1.44 \pm 0.21$ & $\begin{array}{l}25.41 \\
0.36\end{array}$ & $9.33 \pm 0.47$ \\
\hline 89 & BF hitam & $26.71 \pm 2.92$ & $1.48 \pm 0.04$ & $\begin{array}{ll}22.86 & \pm \\
1.02 & \end{array}$ & $7.14 \pm 0.41$ \\
\hline 91 & Q hitam & $28.02 \pm 1.65$ & $1.39 \pm 0.11$ & $26.10 \pm 2.2$ & $7.55 \pm 1.87$ \\
\hline 95 & AM hitam & $28.09 \pm 5.96$ & $1.62 \pm 0.11$ & $\begin{array}{l}22.37 \\
0.22\end{array}$ & $9.14 \pm 1.03$ \\
\hline 98 & J hitam & $41.08 \pm 10.26$ & $1.36 \pm 0.08$ & $\begin{array}{l}23.99 \\
0.10\end{array}$ & $10.65 \pm 0.64$ \\
\hline 100 & BK hitam & $32.27 \pm 1.95$ & $1.64 \pm 0.10$ & $\begin{array}{ll}23.09 & \pm \\
0.92 & \end{array}$ & $12.16 \pm 0.57$ \\
\hline 107 & AN hitam & $31.83 \pm 1.31$ & $1.39 \pm 0.07$ & $21.40 \pm 1.03$ & $11.04 \pm 2.12$ \\
\hline 113 & AH hitam & $34.43 \pm 4.80$ & $1.48 \pm 0.05$ & $26.65 \pm 0.74$ & $8.86 \pm 0.73$ \\
\hline 116 & IR 64 & $30.64 \pm 6.88$ & $1.78 \pm 0.11$ & $25.98 \pm 0.68$ & $9.49 \pm 0.79$ \\
\hline 117 & Situpatenggang-1 & $31.60 \pm 6.49$ & $1.54 \pm 0.07$ & $\begin{array}{l}24.42 \\
0.63 \\
\end{array}$ & $11.4 \pm 0.43$ \\
\hline Rerata & & $28.95 \pm 4.22$ & $1.51 \pm 0.11$ & $\begin{array}{l}23.89 \\
0.86 \\
\end{array}$ & $8.51 \pm 0.81$ \\
\hline
\end{tabular}

Berdasarkan tabel 1 diketahui panjang daun bendera 21 nomor tanaman padi dan diketahui bahwa rata-rata populasi panjang daun bendera sebesar $28.95 \pm 4.22 \mathrm{~cm}$. Hal ini menunjukkan bahwa tanaman padi yang diamati memiliki panjang daun bendera yang seragam dengan kisaran 4.22. Komnas Plasma Nutfah (2003) mengelompokkan panjang daun bendera ke dalam kategori sangat pendek $(<21 \mathrm{~cm})$, pendek $(21-40 \mathrm{~cm})$, sedang, $(41-60 \mathrm{~cm})$, panjang $(61-80 \mathrm{~cm})$, dan sangat panjang $(>80 \mathrm{~cm})$. Karakter panjang daun bendera yang diamati dan diteliti pada tanaman padi nomor aksesi 98 
atau $\mathrm{J}$ hitam dengan panjang sebesar $41.08 \pm 10.26 \mathrm{~cm}$ merupakan daun bendera terpanjang sedangkan nomor aksesi 23 atau $\mathrm{UGM}^{\star} 2$ memiliki panjang daun bendera terpendek dengan panjang $20.24 \pm 1.89 \mathrm{~cm}$. Morfologi daun bendera ini memiliki pengaruh terhadap daya hasil, kualitas biji, dan preferensi hama dalam produksi padi (Fan et al., 2007).

Pada karakter lebar daun memiliki lebar rata-rata populasi sebesar $1.51 \pm 0.11$ $\mathrm{cm}$. Hal ini menunjukkan bahwa lebar daun bendera 21 tanaman padi yang diamati memiliki lebar daun bendera yang hampir seragam karena memiliki standar deviasi atau kisaran yang cukup kecil yaitu sebesar $0.11 \mathrm{~cm}$. Daun bendera nomor aksesi 116 atau IR 64 memiliki daun bendera terlebar yaitu sebesar $1.78 \pm 0.11 \mathrm{~cm}$ sedangkan nomor aksesi 24 atau $\mathrm{BH}$ memiliki lebar daun bendera tersempit yaitu sebesar $1.18 \pm 0.02 \mathrm{~cm}$. Dere dan Yildirim (2006) menyatakan bahwa daun bendera berpengaruh terhadap daya hasil karena daun bendera berperan sebagai distributor asimilat hasil fotosintesis kemalai. Peningkatan panjang dan lebar daun bendera diikuti oleh peningkatan daya hasil karena distribusi asimilat semakin baik. Meskipun demikian, peningkatan panjang dan lebar daun bendera terhadap daya hasil tidak bersifat kontinyu.

Panjang malai memiliki pengaruh terhadap jumlah bakal gabah dengan kecenderungan semakin panjang malai semakin banyak bakal gabah yang terbentuk. Panjang malai menurut Sajak (2012) dikelompokkan menjadi tiga kelompok yakni pendek $(\leq 20 \mathrm{~cm})$, sedang $(20-30 \mathrm{~cm})$, dan panjang $(>30 \mathrm{~cm})$. Panjang malai rata-rata kedua puluh satu galur padi yang diteliti sebesar $23.89 \pm 0.86 \mathrm{~cm}$ dan menurut Sajak (2012) termasuk dalam kategori sedang. Pada penelitian ini karakter panjang malai dengan rerata tertinggi sebesar $26.94 \pm 0.92 \mathrm{~cm}$ dan terendah sebesar $21.4 \pm 1.03 \mathrm{~cm}$. Berdasarkan rerata tersebut dapat dikatakan bahwa semua nomor tanaman padi yang diamati memiliki karakter panjang malai sedang. Hal ini juga menunjukkan bahwa pada karakter panjang malai memiliki keragaman yang terlihat dari standar deviasinya.

Kepadatan malai berkaitan dengan cabang malai primer dan sekunder, semakin banyak malai primer dan sekunder maka akan meningkatkan kepadatan malai. Kepadatan malai merupakan faktor terpenting dalam mempengaruhi hasil padi. Menurut Dewey and Lu (1989) meskipun kemasakan seragam, tetapi kepadatan malai tidak optimum, maka hasil yang optimal tidak dapat dicapai. Ratarata populasi kepadatan malai 21 nomor aksesi sebesar 8.51 butir/cm dengan standar deviasi sebesar 0.81 . Artinya pada populasi tersebut terdapat keragaman kepadatan malai sebesar 0.85 . Padi dengan nomor aksesi 100 atau BK hitam memiliki nilai kepadatan malai tertinggi yaitu sebesar 12.16 butir/cm dengan standar deviasi 0.57 , sedangkan terendah terdapat pada 
nomor aksesi 23 atau UGM*2 yaitu sebesar 5.86 dengan standar deviasi 0.73 . Hal ini menunjukkan bahwa karakter kepadatan malai pada nomor-nomor aksesi tersebut seragam.

Karakter-karakter morfologi lainnya dalam pengamatan ini antara lain sudut daun bendera, cabang malai sekunder, poros malai, tipe malai, bentuk gabah, bentuk beras, dan warna beras yang ditampilkan pada tabel 2. Identifikasi yang dilakukan pada karakter sudut daun bendera, cabang malai sekunder, poros malai, tipe malai, bentuk gabah, bentuk beras, dan warna beras berdasarkan panduan karakterisasi padi yang diterbitkan oleh Komisi Nasional Plasma Nutfah (2003). Karakter sudut daun bendera pada pengamatan ini dapat diketahui bahwa semua tanaman padi memiliki karakter sudut daun bendera tegak. Pada pengamatan cabang malai sekunder sebanyak 16 nomor aksesi yang diamati memiliki karakter cabang malai sekunder sedikit, 3 nomor aksesi banyak, dan 2 nomor aksesi yang tidak bercabang. Pengamatan karakter poros malai sebanyak 20 tanaman padi yang diteliti memiliki poros malai yang masuk kategori terkulai dan sebanyak 1 nomor tanaman padi masuk kategori lurus.

Pada pengamatan tipe malai terdapat dua nomor aksesi padi yang diteliti memiliki tipe kompak, sembilan galur bertipe antara kompak dan sedang, dan sepuluh nomor galur bertipe sedang. Pada karakter bentuk gabah dan beras sebanyak 1 nomor aksesi memiliki bentuk lonjong, 7 nomor galur memiliki bentuk sedang, dan 13 nomor aksesi memiliki bentuk ramping. Pada pengamatan warna beras atau gabah pecah kulit terlihat adanya keragaman. Tanaman padi dengan warna beras putih terdapat pada nomor 5 (Inpago 5), 17 (Arif), 22 (Inpago 6), 23 (UGM*2), 53 (NN-3), 55 (NN-5), 59 (NN-9), 116 (IR 64), dan 117 (Situ Patenggang1), warna bercak-bercak kecil/coklat terdapat pada nomor 3 (MSP-18 hitam), 95 (AM hitam), 98 (J hitam), dan 107 (AN hitam), dan warna ungu terdapat 
Widyaningtias et al. / Vegetalika. 2020. 9(2): 399-413

Tabel 2. Karakter Sudut Daun Bendera (SDB), Cabang Malai Sekunder (CMS), Poros Malai (PRM), Tipe Malai (TM), Bentuk Gabah (BG), Bentuk Beras

\begin{tabular}{|c|c|c|c|c|c|c|c|c|}
\hline $\begin{array}{l}\text { No } \\
\text { Aksesi }\end{array}$ & Nama Aksesi & SDB & CMS & PRM & $\mathrm{TM}$ & BG & BB & WB \\
\hline 1 & Sembada hitam & Tegak & Sedikit & Terkulai & Kompak & Ramping & Ramping & Ungu \\
\hline 3 & MSP-18 hitam & Tegak & Banyak & Terkulai & Antara kompak dan sedang & Sedang & Sedang & Bercak-bercak kecil/coklat \\
\hline 5 & Inpago 5 & Tegak & Sedikit & Terkulai & Sedang & Sedang & Sedang & Putih \\
\hline 11 & Situ Patenggang & Tegak & Sedikit & Terkulai & Sedang & Sedang & Sedang & Ungu \\
\hline 17 & Arif & Tegak & Sedikit & Terkulai & Kompak & Ramping & Ramping & Putih \\
\hline 22 & Inpago 6 & Tegak & Banyak & Terkulai & Antara kompak dan sedang & Ramping & Ramping & Putih \\
\hline 23 & UGM 2* & Tegak & Sedikit & Terkulai & Sedang & Ramping & Ramping & Putih \\
\hline 24 & $\mathrm{BH}$ & Tegak & Banyak & Terkulai & Antara kompak dan sedang & Sedang & Sedang & Ungu \\
\hline 53 & NN-3 & Tegak & Sedikit & Terkulai & Antara kompak dan sedang & Ramping & Ramping & Putih \\
\hline 55 & NN-5 & Tegak & Sedikit & Terkulai & Sedang & Lonjong & Lonjong & Putih \\
\hline 59 & NN-9 & Tegak & Sedikit & Terkulai & Sedang & Ramping & Ramping & Putih \\
\hline 66 & Situbagendit & Tegak & Sedikit & Terkulai & Antara kompak dan sedang & Sedang & Sedang & Merah \\
\hline 89 & BF hitam & Tegak & Sedikit & Terkulai & Antara kompak dan sedang & Ramping & Ramping & Coklat \\
\hline 91 & Q hitam & Tegak & Tak bercabang & Lurus & Antara kompak dan sedang & Ramping & Ramping & Ungu \\
\hline 95 & AM hitam & Tegak & Sedikit & Terkulai & Sedang & Ramping & Ramping & Bercak-bercak kecil/coklat \\
\hline 98 & J hitam & Tegak & Tak bercabang & Terkulai & Antara kompak dan sedang & Ramping & Ramping & Bercak-bercak kecil/coklat \\
\hline 100 & BK hitam & Tegak & Sedikit & Terkulai & Sedang & Ramping & Ramping & Ungu \\
\hline 107 & AN hitam & Tegak & Sedikit & Terkulai & Sedang & Sedang & Sedang & Bercak-bercak kecil/coklat \\
\hline 113 & $\mathrm{AH}$ hitam & Tegak & Sedikit & Terkulai & Sedang & Ramping & Ramping & Ungu \\
\hline 116 & IR 64 & Tegak & Sedikit & Terkulai & Antara kompak dan sedang & Ramping & Ramping & Putih \\
\hline 117 & Situpatenggang-1 & Tegak & Sedikit & Terkulai & Sedang & Sedang & Sedang & Putih \\
\hline
\end{tabular}


pada nomor 1 (Sembada hitam), 11 (Situ Patenggang), 24 (BH), 91 (Q hitam), 100 (BK hitam), dan 113 (AH hitam), dan warna merah pada nomor 66 (Situbagendit) dan coklat terdapat pada nomor 89 (BF hitam). Karakter agronomi juga yang diamati pada penelitian ini. Keragaman agronomi adalah karakter tanaman yang memiliki nilai ekonomis yang berkaitan dengan hasil. Karakter agronomi dalam percobaan ini yaitu tinggi tanaman, jumlah anakan, umur berbunga, umur panen, dan komponen hasil yang terdiri jumlah gabah isi per malai, presentase gabah isi per malai, gabah hampa per malai presentase gabah hampa per malai, bobot 100 butir, dan hasil. Identifikasi karakter agronomi yang dilakukan berdasarkan Panduan Karakterisasi dan Evaluasi Tanaman Padi yang diterbitkan oleh Departemen Pertanian Badan Penelitian dan Pengembangan Pertanian Komisi Nasional Plasma Nutfah (2003). Hasil pengamatan karakter-karakter tersebut ditunjukkan pada tabel 3.

Menurut Abdullah et al. (2008) Padi Tipe Baru (PTB) yang memiliki hasil tinggi memiliki ciri-ciri agronomi tinggi tanaman sedang $(80-100 \mathrm{~cm})$, jumlah anakan sedang tetapi produktif semua (12-18 batang), jumlah gabah per malai 150-250 butir, persentase gabah bernas 85-95\%, bobot 1.000 gabah bernas $2526 \mathrm{~g}$, batang kokoh dan pendek (80-90 cm), umur genjah (110-120 hari), daun tegak, sempit, berbentuk huruf $\mathrm{V}$, berwarna hijau sampai hijau tua, 2-3 daun terakhir tidak cepat luruh, akar banyak dan menyebar dalam, tahan hama dan penyakit utama, gabah langsing, serta mutu beras baik. Berdasarkan tabel 3 dapat diketahui bahwa rata-rata populasi karakter tinggi tanaman yang diamati sebesar $96.93 \pm 4.25 \mathrm{~cm}$ dan masuk dalam kategori pendek dan jumlah anakan produktif sebesar 11.49 dengan kisaran sebesar 1.52 batang dan masuk dalam kategori sedang.

Pada karakter umur berbunga diketahui seragam seperti ditunjukkan dengan rata-rata populasi sebesar 65.5 HSS dengan kisaran 1.10 dan kriteria umur panen tiap nomor tanaman padi dengan rata-rata populasi sebesar 103.56 dengan kisaran 1.76 hari setelah semai dan menurut BB Padi (2015) termasuk dalam klasifikasi sangat genjah. Menurut Kodir et al., (2018) disebutkan bahwa sifat umur panen tanaman padi yang diinginkan pada kegiatan identifikasi dan seleksi adalah berumur sedang (120-145 hari). Berdasarkan tabel 3 diketahui juga rata-rata populasi gabah hampa dua puluh satu nomor padi yang diamati sebesar 36.59 butir atau sebesar $17.29 \%$ dengan kisaran sebesar 7.62 butir dan gabah isi memiliki rata-rata populasi sebesar 166.88 butir atau sebesar $82.71 \%$ dengan kisaran sebesar 16.43 butir. Tanaman padi dengan kehampaan rendah inilah yang diinginkan sebab mampu memiliki hasil yang tinggi. 
Tabel 3 Karakter Gabah Tinggi Tanaman, Jumlah Anakan Produktif, Umur Berbunga, Umur Panen, Gabah Hampa/Malai, Persentase Gabah Hampa/Malai, Jumlah Gabah Isi/Malai, Persentase Gabah Isi/Malai, Bobot 100 Butir, dan Hasil 21 Nomor Tanaman

\begin{tabular}{|c|c|c|c|c|c|c|c|c|c|c|}
\hline NO & $\begin{array}{l}\text { Tinggi } \\
(\mathrm{cm})\end{array}$ & $\begin{array}{l}\sum \text { Anakan } \\
\text { Produktif } \\
\text { (batang) }\end{array}$ & $\begin{array}{l}\text { Umur } \\
\text { Berbunga } \\
\text { (HSS) }\end{array}$ & $\begin{array}{l}\text { Umur Panen } \\
\text { (HSS) }\end{array}$ & $\begin{array}{l}\text { Gabah } \\
\text { Hampa/Malai } \\
\text { (butir) }\end{array}$ & $\begin{array}{l}\text { Gabah } \\
\text { Hampa/Malai } \\
(\%)\end{array}$ & $\begin{array}{l}\text { Gabah } \\
\text { Isi/Malai (butir) }\end{array}$ & $\begin{array}{l}\text { Gabah } \\
\text { Isi/Malai } \\
(\%)\end{array}$ & $\begin{array}{l}\text { Bobot } 100 \\
\text { Butir }(g)\end{array}$ & $\begin{array}{l}\text { Hasil } \\
(\mathrm{kg})\end{array}$ \\
\hline 1 & $96.11 \pm 3.47$ & $10.67 \pm 2.23$ & $64 \pm 0$ & $96 \pm 0$ & $33.56 \pm 9.72$ & 18.61 & $146.78 \pm 20.05$ & 81.39 & $3.14 \pm 0.07$ & $6.53 \pm 1.99$ \\
\hline 3 & $109.78 \pm 6.69$ & $12.89 \pm 1.03$ & $80 \pm 0$ & $117 \pm 0$ & $23.67 \pm 1.36$ & 14.86 & $135.56 \pm 16.78$ & 85.14 & $2.51 \pm 0.07$ & $9.03 \pm 1.37$ \\
\hline 5 & $118.56 \pm 3.95$ & $12.89 \pm 1.1$ & $65.67 \pm 2.36$ & $103 \pm 5.72$ & $27.44 \pm 3.36$ & 16.37 & $140.22 \pm 21.53$ & 83.63 & $3.26 \pm 0.08$ & $6.89 \pm 1.07$ \\
\hline 11 & $90.33 \pm 2.88$ & $10.89 \pm 1.29$ & $80 \pm 0$ & $110 \pm 0$ & $22.00 \pm 2.83$ & 13.95 & $135.67 \pm 11.79$ & 86.05 & $2.49 \pm 0.37$ & $6.42 \pm 1.84$ \\
\hline 17 & $105.33 \pm 5.91$ & $11.67 \pm 1.25$ & $80 \pm 0$ & $111.67 \pm 2.36$ & $40 \pm 14.88$ & 18.90 & $171.67 \pm 21.75$ & 81.10 & $3.11 \pm 0.34$ & $7.22 \pm 1.19$ \\
\hline 22 & $112.56 \pm 1.81$ & $9.89 \pm 1.4$ & $69 \pm 0$ & $110 \pm 0$ & $22.44 \pm 4.4$ & 11.00 & $181.67 \pm 3.30$ & 89.00 & $3.35 \pm 0.06$ & $8.72 \pm 1.26$ \\
\hline 23 & $73.91 \pm 13.39$ & $15.22 \pm 2.27$ & $69 \pm 0$ & $103 \pm 0$ & $12.44 \pm 5.02$ & 9.92 & $113.00 \pm 11.08$ & 90.08 & $3.04 \pm 0.21$ & $6.03 \pm 0.44$ \\
\hline 24 & $85.78 \pm 2.74$ & $12.22 \pm 1.1$ & $64 \pm 0$ & $103 \pm 0$ & $20.77 \pm 4.87$ & 10.87 & $170.33 \pm 1.41$ & 89.13 & $2.37 \pm 0.57$ & $6.11 \pm 1.04$ \\
\hline 53 & $96.78 \pm 2.47$ & $10.11 \pm 2.01$ & $65.67 \pm 2.36$ & $96 \pm 0$ & $27.22 \pm 11.81$ & 13.06 & $181.22 \pm 17.42$ & 86.94 & $2.85 \pm 0.18$ & $9.10 \pm 2.80$ \\
\hline 55 & $110.67 \pm 10.3$ & $12.56 \pm 2.62$ & $63.67 \pm 4.46$ & $100.67 \pm 3.30$ & $30.56 \pm 12.93$ & 18.33 & $136.11 \pm 30.14$ & 81.67 & $2.96 \pm 0.18$ & $6.22 \pm 1.90$ \\
\hline 59 & $91.44 \pm 2.83$ & $11.11 \pm 0.96$ & $62.07 \pm 2.86$ & $96 \pm 0$ & $33.11 \pm 5.82$ & 20.85 & $125.67 \pm 9.12$ & 79.15 & $3.76 \pm 0.4$ & $8.36 \pm 0.89$ \\
\hline 66 & $94.89 \pm 2.83$ & $10.22 \pm 0.57$ & $60.07 \pm 2.86$ & $103 \pm 0$ & $44.33 \pm 1.78$ & 18.66 & $193.22 \pm 15.98$ & 81.34 & $2.9 \pm 0.04$ & $6.28 \pm 0.68$ \\
\hline 89 & $85.44 \pm 4.24$ & $13.67 \pm 1.78$ & $58 \pm 0$ & $103 \pm 0$ & $19.44 \pm 2.94$ & 11.94 & $143.44 \pm 3.72$ & 88.06 & $2.77 \pm 0.06$ & $9.86 \pm 1.93$ \\
\hline 91 & $90 \pm 0.82$ & $12.78 \pm 3.14$ & $69 \pm 0$ & $110 \pm 0$ & $19.33 \pm 5.31$ & 9.68 & $180.44 \pm 57.17$ & 90.32 & $2.85 \pm 0.18$ & $3.36 \pm 1.76$ \\
\hline 95 & $88.22 \pm 3.27$ & $10.00 \pm 2.36$ & $58 \pm 0$ & $103 \pm 0$ & $40.44 \pm 5.94$ & 19.80 & $163.78 \pm 20.59$ & 80.20 & $2.69 \pm 0.06$ & $5.56 \pm 1.53$ \\
\hline 98 & $91.22 \pm 4.76$ & $12.22 \pm 2.20$ & $60.07 \pm 2.86$ & $103 \pm 0$ & $59.56 \pm 11.86$ & 23.25 & $196.56 \pm 7.49$ & 76.75 & $2.55 \pm 0.16$ & $5.14 \pm 0.79$ \\
\hline 100 & $87.11 \pm 3.71$ & $12.33 \pm 0.72$ & $69 \pm 0$ & $111.67 \pm 2.36$ & $74.00 \pm 6.33$ & 26.22 & $208.22 \pm 4.41$ & 73.78 & $2.56 \pm 0.24$ & $4.86 \pm 0.98$ \\
\hline 107 & $92 \pm 4.72$ & $10.44 \pm 2.06$ & $58 \pm 0$ & $103.78 \pm 1.10$ & $69.67 \pm 28.12$ & 29.33 & $167.89 \pm 26.21$ & 70.67 & $2.57 \pm 0.08$ & $6.19 \pm 0.63$ \\
\hline 113 & $95.79 \pm 2.02$ & $12.43 \pm 0.17$ & $60.57 \pm 2.56$ & $89.70 \pm 18.81$ & $40.33 \pm 2.94$ & 17.41 & $191.29 \pm 10.14$ & 82.59 & $3.47 \pm 0.18$ & $7.70 \pm 0.74$ \\
\hline 116 & $102.22 \pm 1.91$ & $9.00 \pm 0.82$ & $58 \pm 0$ & $105.33 \pm 3.30$ & $30.33 \pm 11.57$ & 12.06 & $221.11 \pm 32.22$ & 87.94 & $3.39 \pm 0.28$ & $11.42 \pm 3.12$ \\
\hline 117 & $117.44 \pm 4.42$ & $8.11 \pm 0.83$ & $62.07 \pm 2.86$ & $96 \pm 0$ & $77.78 \pm 6.31$ & 27.94 & $200.56 \pm 2.73$ & 72.06 & $3.32 \pm 0.19$ & $7.06 \pm 0.34$ \\
\hline Rerata & $96.93 \pm 4.25$ & $11.49 \pm 1.52$ & $65.5 \pm 1.10$ & $103.56 \pm 1.76$ & $36.59 \pm 7.62$ & 17.29 & $166.88 \pm 16.43$ & 82.71 & $2.95 \pm 0.19$ & $7.05 \pm 1.35$ \\
\hline
\end{tabular}


Salah satu kriteria yang digunakan untuk mengukur kemampuan pengisian bulir padi adalah berat 100 butir. Pada tabel 3 diketahui rata-rata populasi bobot 100 gram 21 tanaman sebesar 2.95 \pm 0.19 gram. Menurut standar IBPGR (1980) karakter bobot 100 butir pada penelitian ini termasuk dalam kategori sedang dan berat. Menurut Manurung dan Ismunadji (1988) cit. Putih et al. (2011) bobot 100 butir gabah bernas relatif tetap, hal ini dikarenakan bobot tersebut berganung pada ukuran lemma dan palea yang ukuran maksimalnya terbentuk 5 hari setelah berbunga sesuai genetiknya.

Hasil produksi merupakan salah satu faktor penting yang dijadikan pertimbangan dalam perakitan varietas. Pada tabel 3 diketahui rata-rata populasi hasil 21 tanaman sebesar $7.05 \pm 1.35 \mathrm{~kg}$. Pada nomor 116 (IR64) memiliki hasil tertinggi sebesar $11.42 \pm 3.12 \mathrm{~kg}$, sedangkan terendah pada nomor 91 ( $Q$ hitam) sebesar $3.36 \pm 1.76$. Padi nomor 116 (IR64) merupakan padi varietas unggul baru yang memiliki sifat-sifat unggul dan hasil tinggi, sedangkan nomor 91 (Q hitam) meskipun memiliki hasil terendah namun tingkat kehampaan terendah. Padi nomor 91 (Q hitam) dapat dijadikan tetua untuk pembuatan varietas padi baru dengan tingkat kehampaan rendah dan untuk menentukan karakter-krakter yang menetukan kehampaan malai dapat diketahui dengan menggunakan analisis korelasi fenotipik dan genotipik, serta analisis lintas yang ditampilkan pada tabel 4 dan 5.

Hardiyanto (2008) mengatakan bahwa korelasi fenotipik merupakan korelasi di antara nilai yang diukur dari dua sifat pada suatu populasi, sedangkan korelasi genetik merupakan korelasi antara nilai pemuliaan (breeding value) untuk sifat yang berbeda dan terutama disebabkan oleh gen-gen yang mempengaruhi lebih dari satu sifat (pleiotrof). Berdasarkan tabel 4 hasil analisis korelasi karakter morfologi dan agronomi yang bernilai positif dengan gabah hampa yaitu panjang daun bendera dengan nilai $r$ fenotip $=0.36$ dan $r$ genotip $=0.75$, anakan produktif dengan nilai $r$ genotip $=-0.83$, kepadatan malai dengan nilai $r$ fenotip $=0.81$ dan $r$ genotip $=0.91$, dan gabah isi dengan nilai $r$ fenotip $=0.46$ dan $r$ genotip $=0.63$. Singh dan Chaudhary $(1985)$ menyatakan bahwa hubungan dua variabel atau lebih dinyatakan positif bila nilai suatu variabel ditingkatkan, maka akan meningkatkan variabel yang lain. Dengan demikian jika karakter panjang daun bendera, kepadatan malai, dan gabah isi ditingkatkan akan meningkatkan kehampaan malai, sedangkan peningkatan anakan produktif akan menurunkan tingkat kehampaan malai. 
Tabel 4 Koefisien Korelasi Fenotip dan Genotip Komponen Morfologi dan Agronomi dengan Kehampaan Malai

\begin{tabular}{|c|c|c|c|c|c|c|c|c|c|c|c|c|c|}
\hline & & $\mathrm{tt}$ & $\mathrm{pdb}$ & $\mathrm{Idb}$ & ap & $\mathrm{pm}$ & $\mathrm{km}$ & b100 & $u b$ & up & gi & hasil & gh \\
\hline \multirow[t]{2}{*}{$\mathrm{tt}$} & $\mathrm{rp}$ & 1 & 0.14 & $0.39^{*}$ & $-0.25^{*}$ & 0.1 & 0.19 & $0.33^{*}$ & 0.11 & 0.04 & 0.19 & $0.28^{*}$ & 0.16 \\
\hline & $\mathrm{rg}$ & 1 & 0.13 & $0.59^{*}$ & -0.62 & 0.05 & 0.13 & $0.42^{*}$ & 0.19 & 0.06 & 0.12 & $0.35^{*}$ & 0.13 \\
\hline \multirow[t]{2}{*}{$\mathrm{pdb}$} & $\mathrm{rp}$ & & 1 & -0.08 & -0.02 & $0.33^{*}$ & $0.45^{*}$ & -0.17 & -0.19 & 0 & $0.53^{*}$ & 0.01 & $0.36^{*}$ \\
\hline & $\mathrm{rg}$ & & 1 & -0.07 & -0.31 & $0.46^{*}$ & $0.73^{*}$ & -0.55 & -0.28 & 0.11 & $0.8^{*}$ & $-0.43^{*}$ & $0.75^{*}$ \\
\hline \multirow[t]{2}{*}{$\mathrm{Idb}$} & $\mathrm{rp}$ & & & 1 & -0.23 & 0.03 & 0.08 & 0.23 & 0.08 & 0.15 & 0.1 & 0.24 & 0.04 \\
\hline & $\mathrm{rg}$ & & & 1 & -0.45 & -0.17 & 0.22 & $0.54^{*}$ & 0.12 & 0.2 & 0.15 & $0.62^{*}$ & 0.15 \\
\hline \multirow[t]{2}{*}{ ap } & $\mathrm{rp}$ & & & & 1 & 0.05 & -0.2 & -0.17 & 0.16 & 0.15 & -0.16 & -0.13 & -0.14 \\
\hline & $\mathrm{rg}$ & & & & 1 & -0.42 & $-0.99^{*}$ & -0.37 & $0.39^{*}$ & 0.28 & $-0.92^{*}$ & -0.49 & $-0.83^{*}$ \\
\hline \multirow[t]{2}{*}{$\mathrm{pm}$} & $\mathrm{rp}$ & & & & & 1 & 0 & 0.06 & -0.16 & -0.21 & $0.47^{*}$ & 0.04 & 0.03 \\
\hline & $\mathrm{rg}$ & & & & & 1 & -0.09 & 0.13 & -0.16 & -0.37 & 0.43 & -0.17 & -0.03 \\
\hline \multirow[t]{2}{*}{$\mathrm{km}$} & $\mathrm{rp}$ & & & & & & 1 & -0.05 & $-0.27^{*}$ & -0.03 & $0.8^{*}$ & -0.05 & $0.81^{*}$ \\
\hline & $\mathrm{rg}$ & & & & & & 1 & -0.06 & -0.33 & 0.07 & 0.81 & -0.16 & $0.91^{*}$ \\
\hline \multirow[t]{2}{*}{ b100 } & $\mathrm{rp}$ & & & & & & & 1 & -0.16 & $-0.38^{*}$ & -0.04 & $0.29^{*}$ & 0.01 \\
\hline & $\mathrm{rg}$ & & & & & & & 1 & -0.25 & -0.59 & 0.08 & $0.54^{*}$ & -0.12 \\
\hline \multirow[t]{2}{*}{ ub } & $\mathrm{rp}$ & & & & & & & & 1 & $0.52^{*}$ & $-0.27^{*}$ & -0.11 & -0.24 \\
\hline & $\mathrm{rg}$ & & & & & & & & 1 & $0.74^{*}$ & -0.34 & -0.06 & $-0.33^{*}$ \\
\hline \multirow[t]{2}{*}{ up } & $\mathrm{rp}$ & & & & & & & & & 1 & -0.04 & -0.1 & -0.12 \\
\hline & $\mathrm{rg}$ & & & & & & & & & & 0.01 & -0.12 & -0.15 \\
\hline \multirow[t]{2}{*}{ gi } & $\mathrm{rp}$ & & & & & & & & & & 1 & 0.07 & $0.46^{*}$ \\
\hline & $\mathrm{rg}$ & & & & & & & & & & 1 & -0.03 & $0.63^{*}$ \\
\hline \multirow[t]{2}{*}{ hasil } & $\mathrm{rp}$ & & & & & & & & & & & 1 & -0.15 \\
\hline & $\mathrm{rg}$ & & & & & & & & & & & 1 & -0.39 \\
\hline \multirow[t]{2}{*}{ gh } & $\mathrm{rp}$ & & & & & & & & & & & & 1 \\
\hline & & & & & & & & & & & & & 1 \\
\hline
\end{tabular}

Keterangan $: \mathrm{tt}=$ tinggi tanaman, $\mathrm{pdb}=$ panjang daun bendera, Idb = lebar daun bendera, ap = anakan produktif, $\mathrm{km}=$ kepadatan malai, b100 = bobot 100 butir, ub = umur berbunga, up = umur panen, gi = gabah isi $/$ malai, hasil $=$ hasil, $g h=$ gabah hampa $/$ malai, ${ }^{*}$ berbeda nyata pada $\alpha 5 \%$

Tabel 5 Koefisien Lintas terhadap Kehampaan Malai

\begin{tabular}{lllllll}
\hline & $\mathrm{pdb}$ & $\mathrm{ap}$ & $\mathrm{km}$ & $\mathrm{gi}$ & $\mathrm{ub}$ & $\mathrm{gh}$ \\
\hline $\mathrm{pdb}$ & $\mathbf{0 . 2 3}$ & 0.01 & 0.64 & -0.36 & 0.01 & 0.53 \\
$\mathrm{ap}$ & -0.03 & $\mathbf{- 0 . 1 0}$ & -0.59 & 0.31 & -0.01 & -0.4 \\
$\mathrm{~km}$ & 0.13 & 0.05 & $\mathbf{1 . 1 2}$ & -0.45 & 0.02 & 0.87 \\
$\mathrm{gi}$ & 0.15 & 0.06 & 0.90 & $\mathbf{- 0 . 5 6}$ & 0.02 & 0.55 \\
$\mathrm{ub}$ & -0.05 & -0.03 & -0.35 & 0.18 & $\mathbf{- 0 . 0 5}$ & -0.3 \\
\hline
\end{tabular}

$\mathrm{pdb}=$ panjang daun bendera, ap = anakan produktif, $\mathrm{km}=$ kepadatan malai, gi = gabah isi/malai, $\mathrm{ub}=$ umur berbunga, $\mathrm{gh}=$ gabah hampa Nilai yang cetak tebal adalah nilai koefisien korelasi lintas langsung. Residual effect $(R)=0.39$

Pada tabel 5 dapat dilihat bahwa semua variabel yang dianalisis lintas menunjukkan pengaruh tidak langsung terhadap kehampaan. Hal ini dikarenakan nilai koefisien korelasi dan pengaruh langsung memiliki nilai yang selisihnya jauh. Variabel panjang daun bendera memiliki nilai pengaruh langsung 0.23 terhadap gabah hampa per malai, sedangkan nilai pengaruh total sebesar 0.53 . Variabel jumlah anakan produktif memiliki 
nilai pengaruh langsung sebesar -0.10 dengan nilai pengaruh total sebesar -0.4 . Variabel kepadatan malai memiliki nilai pengaruh langsung sebesar 1.12 dengan nilai pengaruh total sebesar 0.87 . Variabel gabah isi nilai pengaruh langsung sebesar -0.56 dan nilai pengaruh total sebesar 0.55 . Variabel umur berbunga memiliki pengaruh langsung sebesar -0.05 dengan nilai pengaruh total sebesar -0.3 . Semua variabel memiliki nilai pengaruh langsung dengan pengaruh total yang tidak hampir sama artinya variabel penentu kehampaan disebabkan oleh pengaruh tidak langsung. Hal ini juga menunjukkan bahwa pengaruh langsung lebih kecil dari pengaruh total, menurut Singh and Chudary (1977) pengaruh tak langsung merupakan penyebab adanya korelasi tersebut sehingga panjang daun bendera bukan menjadi karakter seleksi langsung pada pembuatan tanaman padi dengan kehampaan rendah. Nilai koefisien korelasi pada variabel gabah isi per malai bernilai positif sebesar 0.55 namun pengaruh langsungnya bernilai negatif sebesar -0.56 , maka pengaruh tak langsung merupakan penyebab adanya korelasi tersebut. Karakter gabah isi per malai dapat dijadikan kriteria seleksi kehampaan malai, namun harus memperhatikan variabel kepadatan malai.

Pada tabel 5 diketahui residual effect $(R)$ sebesar 0.39 mengindikasikan bahwa sekitar $61 \%$ variabilitas pada produktivitas disumbangkan oleh karakter-karakter yang diamati dalam analisis lintas. Nilai residu mendekati nol artinya analisis sidik lintas yang digunakan sangat efektif menjelaskan sebab akibat dari nilai korelasi dan karakter yang diamati lengkap menjelaskan nilai-nilai pengaruh langsung maupun tak langsungnya. Berdasarkan ukuran faktor residual memberi arti bahwa peubah bebas yang disertakan dalam analisis sidik lintas sudah terwakili yaitu sumbangan total sebesar $61 \%$ dapat dijelaskan oleh peubah bebas yang diamati, sedangkan nilai residual effect atau nilai sisaan $(R=0.39)$ dijelaskan peubah bebas lain yang tidak diamati (Simatupang, 2009).

\section{KESIMPULAN}

Kehampaan mampu mengurangi gabah isi sebesar $29.33 \%$ yang disebabkan oleh karakter morfologi dan agronomi yakni tinggi tanaman, panjang daun bendera, lebar daun bendera, anakkan produktif, dan panjang malai. Karakter tersebut beragam secara genetik sehingga dapat digunakan sebagai kriteria seleksi menurunkan kehampaan. Aksesi nomor 91 atau $Q$ hitam dan 23 atau UGM*2 memiliki kehampaan rendah masingmasing sebesar $9.68 \%$ dan $9.92 \%$, serta dapat digunakan sebagai tetua persilangan sehingga pada akhirnya hasil bisa ditingkatkan dengan menurunkan kehampaan. 


\section{DAFTAR PUSTAKA}

Abdullah B., S. Tjokrowidjojo, dan Sularjo. 2008. Perkembangan dan Prospek Perakitan Padi Tipe Baru di Indonesia. Jurnal Litbang Pertanian, 27(1).

BB Padi. 2013. Deskripsi varietas padi. Dikompilasi oleh Suharna. BB Padi. Sukamandi.

Dere, S., dan Yildirim, M. B. 2006. Inheritance of Grain Yield per Plant, Flag Leaf Width, and Length in an $8 \times 8$ Diallel Cross Population of Bread Wheat (Triticum aestivum L.). Turk J Agric For 30:339-345.

Dewey, A. A. and K. H. Liu. 1989. A Correlation and Path Coefficient Analysis of Components of Crested Wheatgrass Seeds Production. Agron J. 51:515-518.

Fan, G., Dong Y., Wang C., Wan J., Xie H., Xu C., Zhu, J., Cai, Q. 2007. Analysis of QTLs for Flag Leaf Shape and Its Response to Elevated CO2 in Rice (Oryza sativa). Elsevier BV.

Hardiyanto, E. B. 2008. Diktat Mata Kuliah Pemuliaan Pohon Lanjut. Program Pasca Sarjana. Fakultas Kehutanan. Universitas Gadjah Mada Yogyakarta.

IBPGR. IRRI. 1980. Descibtors for Oryza sativa L. IRRI. Manila.

Kobata T. and Kumi I. 2002. Low grain ripening in the new plant type rice due to shortage of assimilate supply. Agronomy Journal.

Kodir K. A., Y. Juwita, P. Sasmita. 2018. Karakterisasi Padi Lokal, Pegagan (Siputih) pada Agroekosistem Rawa Lebak Sumatra Selatan. Buletin Plasma Nutfah 24(2): 77-82.

Komnas Plasma Nutfah. 2003. Karakterisasi dan Evaluasi Tanaman Padi. Departemen Pertanian, Jakarta.

Peng, S, Khush GS, Cassman KG. 1994. Evaluation of a new plant ideotype for increased yield potential. In: Cassman KG. (Ed.). Breaking the Yield Barrier: Proceedings of a Workshop on Rice Yield Potential in Favourable Environments. International Rice Research Institute. Los Banos, Philippines. pp. 5- 20.

Putih, R., A. Anwar., N. A. Rahma GR. 2011. Variabilitas Genetik Karakter Umur, Hasil, dan Komponen Hasil Beberapa Genotipe Padi Lokal (Oryza sativa L.) Sumatera Barat. Porisiding pada Seminar Nasional "Reformasi Pertanian Terintegrasi Menuju Kedaulatan Pangan”, Padang, 20 Oktober 2011.

Ratna, M., S. Begum, A. Husna, S.R. Dey, and S. Hossain. 2015. Correlation and Path Coefficients Analyses in Basmati Rice. Bangladesh J. Agril. Res. 40(1): 153161, March 2015.

Sajak, A., 2012. Karakterisasi morfologi malai plasma nutfah padi lokal asal Kabupaten Tana Toraja Utara, Sulawesi Selatan. Universitas Hasanuddin, Sulawesi Selatan. 
Simatupang, B. 2009. Kajian Korelasi Antar Sifat Komponen Hasil dan Sidik Ragam Tanaman Kepuh (Sterculia foetida Linn) Terhadap Hasil dan Rendemen Minyak. 2009. Fakutas Pertanian. Universitas Sebelas Maret. Tesis.

Singh RK, Chaudhary BD. 1985. Biometrical Methods In Quantitative Genetics Analysis. New Delhi (IN): Kalyani Publisher.

Yamagishi, T., S. Peng, K. G. Cassman, and R. Ishii. 1996. Studies on grain filling among tillers characteristics in "new plant type" rice lines developed in IRRI. Japan. Journal Crop Science. 65:169-170. 